\title{
Yangambin, a Lignan Obtained from Ocotea duckei, Differentiates Putative PAF Receptor Subtypes in the Gastrointestinal Tract of Rats
}

\author{
Christina M. Q. Jesus-Morais ${ }^{1}$, Edson F. Assis², Renato S. B. Cordeiro², José M. Barbosa-Filho ${ }^{4}$, Wothan T. Lima ${ }^{3}$, \\ Zilma L. Silva ${ }^{3}$, Patrícia T. Bozza², Hugo C. Castro-Faria-Neto²,* \\ 1 INCQS, Instituto Nacional de Controle de Qualidade em Saúde, Fundação Oswaldo Cruz, Rio de Janeiro, Brazil \\ ${ }^{2}$ Departamento de Fisiologia e Farmacodinâmica, IOC, Fundação Oswaldo Cruz, Rio de Janeiro, Brazil \\ ${ }^{3}$ Instituto de Ciências Biomédicas, Universidade de São Paulo, São Paulo, Brazil \\ ${ }^{4}$ Laboratório de Tecnologia Farmacêutica, Universidade Federal de Paraíba, João Pessoa, Paraíba, Brazil
}

Received: June 16, 1999; Accepted: August 1, 1999

\begin{abstract}
We investigated the presence of PAF receptor subtypes in the tissues of the gastrointestinal tract, airways, blood vessels and in murine macrophages. For this purpose we have used a competitive PAF receptor antagonist, yangambin (YAN), extracted from the Brazilian plant "louro de cheiro" (Ocotea duckei Vattimo). Rat duodenum, jejunum, ileum, colon, stomach fundus, trachea and bronchia were removed and $1.5-2 \mathrm{~cm}$ muscle segments from those regions were mounted in a $10 \mathrm{ml}$ organ bath with aerated physiological solution at $37^{\circ} \mathrm{C}$. PAF evoked a contraction of the rat jejunum, ileum, colon and stomach fundus. The contraction was slow and resistant to wash and was followed by desensitization to further doses of PAF. Contractions induced by PAF $\left(10^{-6} \mathrm{M}\right)$ were inhibited by YAN $\left(10^{-7}\right.$ to $\left.\mathrm{M}-2 \times 10^{-5} \mathrm{M}\right)$ and WEB $2086\left(10^{-6} \mathrm{~m}\right.$ to $\left.\mathrm{M}^{-5} \mathrm{M}\right)$ in rat jejunum, ileum and colon but not in the stomach fundus. In the rat stomach fundus only WEB $2086\left(5 \times 10^{-6} \mathrm{M}\right)$ was able to block PAF-induced contraction. The contractions induced by acetylcholine, histamine, 5-hydroxytryptamine and vasopressin were not inhibited by prior administration of YAN. Yangambin also significantly inhibited PAF-induced vascular permeability in rat duodenum, jejunum, ileum, colon, and mesentery. Yangambin significantly inhibited PAF-induced lipid body formation in mice peritoneal macrophages. We suggest that YAN is a selective PAF antagonist which is able to discriminate putative PAF receptors subtypes present in the stomach fundus.
\end{abstract}

Key words: Yangambin, Ocotea duckei, Lauraceae, PAF, PAF-receptor subtypes, natural product.

\section{Introduction}

Platelet-activating factor (PAF) is a lipid mediator able to induce many biological effects such as platelet aggregation, increase in vascular permeability, bronchoconstriction, hypotension and smooth muscle contraction (1). PAF is also able to induce leukocyte activation and was recently shown to be involved in the lipid body formation observed in leukocytes associated with the inflammatory process (2).

Planta Medica 66 (2000) 211-216

(c) Georg Thieme Verlag Stuttgart · New York ISSN: 0032-0943
PAF effects are usually mediated through interaction with specific cell surface receptors although there is evidence suggesting that accumulation of intracellular PAF may also influence cell functions (3). PAF receptors in guinea-pig lung (4), human leukocytes (5), and other cells have been cloned and characterized but so far, no receptor subtypes have been identified by molecular biology techniques.

Due to the amount of evidence indicating the involvement of PAF in pathological conditions such as thrombosis, asthma, sepsis and anaphylaxis (1) a great effort has been taken to identify and develop potent and selective PAF-antagonist receptors (1). One of the most promising areas for identification of new PAF antagonists is the study of substances obtained from plants. Among the many different compounds studied, the family of the lignans, has been shown to present molecules with potent PAF antagonist activity including kadsurenone (6) and veraguesin (7).

We have recently shown that the furofuran lignan yangambin (YAN) (Fig. 1), isolated from the Brazilian plant Ocotea duckei Vattimo (Lauraceae), showed a selective and competitive PAF antagonist activity on platelet aggregation and $\left[{ }^{3} \mathrm{H}\right]-\mathrm{PAF}$ binding to platelets but failed to block PAF-induced neutrophil chemotaxis (8). Pretreatment of rabbits with YAN prevented the PAF effects on cardiovascular system, including hypotension and reduction of heart rate, however the neutropenia elicited by PAF was not affected (9). Moreover, YAN had no effect in PAF-induced oxidative burst and cytokine secretion by human PMN leukocytes (10). Taken together, these data suggest that YAN might discriminate a putative PAF receptor subtype present in the cardiovascular system and platelets from the one existing in polymorphonuclear leukocytes, at least in rabbits, guinea-pigs and humans (8), (9), (10).

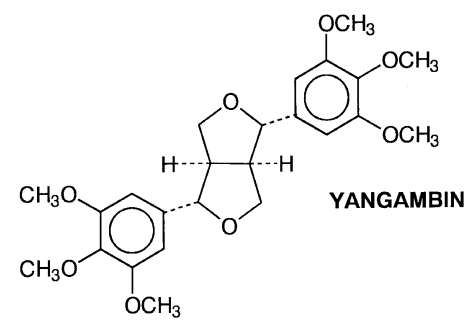

Fig. 1 Structural formula of yangambin. 
Likewise, kadsurenone, which was the first natural product found to be a potent PAF antagonist, had shown the same characteristic of YAN, this neolignan is able to distinguish a putative subtype of PAF receptor present in guinea-pig peritoneal macrophages from the one expressed in pig polymorphonuclear leukocytes (11).

The aim of this study was to investigate the inhibitory activity of YAN on PAF-induced effects on the tissues of the gastrointestinal tract, airways and blood vessels of rats and on murine macrophages aiming to identify additional target tissues where YAN might discriminate putative PAF receptor subtypes.

\section{Materials and Methods}

Animals

Wistar rats (180-300 g) and $\mathrm{C} 3 \mathrm{H} / \mathrm{He}$ mice (20-25 g) of both sexes were obtained from the Oswaldo Cruz animal facility. The animals were maintained with food and water ad libitum.

\section{Isolated tissue preparations}

Rats were killed in a $\mathrm{CO}_{2}$ chamber and the duodenum, jejunum, ileum, colon and stomach fundus were removed; the mesentery was trimmed away and $1.5-2 \mathrm{~cm}$ segments were cut. The duodenum, jejunum, ileum and colon segments were placed in a $10 \mathrm{ml}$ organ bath with aerated Tyrode solution (composition in $\mathrm{mM}$ : $\mathrm{NaCl} 137, \mathrm{KCl} 2.68, \mathrm{NaH}_{2} \mathrm{PO}_{4} \cdot \mathrm{H}_{2} \mathrm{O} 0.42$, $\mathrm{MgCl}_{2} \cdot 6 \mathrm{H}_{2} \mathrm{O} 1.05, \mathrm{NaHCO}_{3}, 11.9, \mathrm{CaCl}_{2} \cdot 2 \mathrm{H}_{2} \mathrm{O} 1.8$ and glucose 5.55) at $37^{\circ} \mathrm{C}$. The fundal part of the stomach can easily be identified because it is grey; it was opened out longitudinally, placed in a dish containing Krebs-Henseleit solution (composition in $\mathrm{mM}: \mathrm{NaCl} 115.0 ; \mathrm{KCl} 4.6 ; \mathrm{CaCl}_{2} \cdot \mathrm{H}_{2} \mathrm{O}$ 2.5; $\mathrm{KH}_{2} \mathrm{PO}_{4} 1.2$; $\mathrm{MgSO}_{4} \cdot 7 \mathrm{H}_{2} \mathrm{O}$ 2.5; $\mathrm{NaHCO}_{3} 25.0$, and glucose 11.0) and made into a strip about $2 \mathrm{~cm}$ long by suitable transverse cuts. Cuts were made in this sheet of muscle so as to produce a strip and the preparation was mounted in a $10 \mathrm{ml}$ organ bath with aerated Krebs' solution at $37^{\circ} \mathrm{C}$.

For the experiments with tissues from the respiratory tract rats were killed by an overdose of $10 \%$ chloral hydrate ( $400 \mathrm{mg} / \mathrm{kg}$, i.p.) and the rat tracheal and bronchial rings were cut through and dissected free. The preparations were mounted in a $8 \mathrm{ml}$ organ bath with Krebs-Henseleit solution, at $37{ }^{\circ} \mathrm{C}$, aerated with $95 \% \mathrm{O}_{2}$ and $5 \% \mathrm{CO}_{2}$.

The contractile activity of the tissue was then assessed by the addition of Krebs bicarbonate solution containing $60 \mathrm{mM} \mathrm{KCl}$. Acetylcholine $\left(10^{-7}\right.$ and $\left.10^{-6} \mathrm{M}\right)$ was added to the bath to test the viability of the tissues. After the contractile response had reached a plateau, the tissues were washed 3 times over a $15 \mathrm{~min}$ period and allowed to equilibrate for a further $60 \mathrm{~min}$.

The tissues were subsequently challenged by PAF. In another series of experiments the effects of pre-incubation with PAFreceptor antagonists WEB 2086 and YAN were evaluated.

Gastrointestinal tract contractions were measured isotonically under a tension of $1 \mathrm{~g}$ using an Ugo Basile transducer connected to polygraph 7006 (Ugo Basile, Italy). Rat tracheal and bronchial rings were set up under a tension of $1 \mathrm{~g}$ and changes in tension were measured isometrically using a Narcotrace 40 system.

\section{Evaluation of vascular permeability}

Vascular permeability was evaluated by the Evans blue (EB) dye extravasation method (12). The EB $(25 \mathrm{mg} / \mathrm{ml}$ in saline; $20 \mathrm{mg} / \mathrm{kg}$ ) was injected concomitantly to PAF ( $5 \mu \mathrm{g} / \mathrm{kg}$ ) into the rat tail vein. Groups of rats were treated intravenously with YAN $(30 \mathrm{mg} / \mathrm{kg})$ or WEB $2086(1 \mathrm{mg} / \mathrm{kg}), 30 \mathrm{~min}$ before $\mathrm{PAF}$ injection. The control group consisted of rats injected in the tail vein only with EB. The animals were killed by decapitation and were exsanguinated 10 min later. The thorax and abdomen were cut open and the duodenum, jejunum, ileum, colon, and mesentery were removed, dissected, weighed, and a fragment of each organ was put in formamide $(4 \mathrm{ml} / \mathrm{g}$ wet weight tissue at $20^{\circ} \mathrm{C}$ for $24 \mathrm{~h}$ ) for EB dye extraction, whereas another fragment was dried at $60{ }^{\circ} \mathrm{C}$ for $24 \mathrm{~h}$. The concentration of EB was determined by spectrophotometry at a wavelength of $620 \mathrm{~nm}$. The results were plotted on a standard curve of EB $(0.5-25 \mu \mathrm{g} / \mathrm{ml})$ and the content of each sample was expressed as $\mu \mathrm{g}$ of $\mathrm{EB} / \mathrm{g}$ dry weight tissue.

\section{Lipid body formation, staining and enumeration}

Mice were killed in a $\mathrm{CO}_{2}$ chamber and the peritoneal cavities were washed with $5 \mathrm{ml}$ of $\mathrm{Ca}^{2+} / \mathrm{Mg}^{2+}$-free HBSS. A $5 \mu$ l sample of the peritoneal fluid was diluted in Turk fluid (2\% acetic acid) for total leukocyte counts in a hemocytometer. Peritoneal leukocytes $\left(10^{6} \mathrm{cells} / \mathrm{ml}\right)$ were incubated in HBSS with PAF $10^{-6} \mathrm{M}$ or vehicle at $37^{\circ} \mathrm{C}$ for $1 \mathrm{~h}$. Leukocytes were cytocentrifuged ( $500 \mathrm{rpm}, 5 \mathrm{~min}$ ) onto glass slides. Slides, while still moist, were fixed in $3.7 \%$ formaldehyde in $\mathrm{Ca}^{2+} / \mathrm{Mg}^{2}$-free HBSS; $\mathrm{pH} 7.4$, rinsed in $0.1 \mathrm{M}$ cacodylate buffer $(\mathrm{pH} 7.4)$ stained in $1.5 \% \mathrm{OsO}_{4}(30 \mathrm{~min})$, rinsed in distilled $\mathrm{H}_{2} \mathrm{O}$, immersed in $1.0 \%$ thiocarbohydrazide $(5 \mathrm{~min})$, rinsed in $0.1 \mathrm{M}$ cacodylate buffer, restained in $1.5 \% \mathrm{OsO}_{4}(3 \mathrm{~min})$, rinsed in distilled $\mathrm{H}_{2} \mathrm{O}$, and then dried and mounted. The morphology of fixed cells was observed, and lipid bodies were enumerated by phase contrast microscopy with an objective lens at a magnification of 100 in 50 consecutively scanned macrophages and expressed as lipid bodies number per cell. During inhibition studies, leukocytes were pretreated for $15 \mathrm{~min}$ with the receptor antagonists: YAN $10^{-5} \mathrm{M}$ or BN $5202110^{-5} \mathrm{M}$ or vehicle as indicated.

\section{Preparation of yangambin}

Spectroscopically pure YAN was obtained from dried leaves of $0 . d u c k e i$ according to the procedures previously described (10). Leaves of O. duckei were collected in João Pessoa, State of Paraíba, Brazil. A voucher specimen is deposited at the herbarium of the Federal University of Paraíba, Brazil. Experimental data confirmed the identity of the isolate with (+)-yangambin as previously described: melting point $123-125^{\circ} \mathrm{C}$ (from hexane/AcOEt); optical rotation: $[\alpha]_{\mathrm{D}}:+50^{\circ}$ in $\mathrm{CHCl}_{3}$; EIMS $(70 \mathrm{eV}): \mathrm{m} / \mathrm{z}(\%)=446[\mathrm{M}]^{+}(22) ; 224$ (16); 207 (59); 195 (63); 181 (100); 167 (10).

\section{Drugs}

PAF (1-0-hexadecyl-2-acetyl-sn-glyceryl-3-phosphorylcholine, powder from Sigma) was dissolved and further diluted in 
saline containing $0.25 \%$ bovine serum albumin (Sigma). Chloral hydrate, cremophor EI, acetylcholine and histamine were obtained from Sigma Chemical CO, St. Louis, MO. WEB 2086 \{(3-4-(2-chlorophenyl)-9-methyl-6H-thieno[3,2-f;1,2,4]triazolo[4,3-a;1,4]diazepin-2-yl-(4-morpholinyl)-1-propanone\} was from Boehringer Ingelheim, Germany; BN 52021 \{(3-(1,1dimethylethyl)-hexahydro-1,4,7b-trihydroxy-8-methyl-9H-1, 7-(epoxymethano)-1H,6H-cyclopenta[c]furo[2,3-b]furo(3,2:3,4) cyclopenta[1,2-d]furan-5,9,12(4H)-trione $\}$ was a gift of $\mathrm{Dr}$. Pierre Braquet. All drugs were dissolved in normal saline solution $(0.9 \% \mathrm{NaCl})$, with the exception of YAN which was dissolved in cremophor EI (1\% final concentration) and further diluted with saline.

\section{Statistical analysis}

The results were expressed as mean \pm S.E.M., and analyzed statistically by the analysis of variance (ANOVA) followed by the Newman-Keuls or Student test. P values of 0.05 or less were considered significant.

\section{Results}

\section{Effect of PAF and YAN treatment on isolated rat intestine}

PAF induced a sustained contraction of the isolated jejunum, ileum and colon. The contractions were slow and resistant to the washes and followed by tachyphylaxis. Preincubation with YAN $\left(10^{-6} \mathrm{M}\right)$ inhibited PAF-induced jejunum, ileum and colon contraction (Fig. 2a, b, c). Preincubation with YAN $\left(10^{-6} \mathrm{M}\right)$ failed to inhibit the ileum contraction induced by acetylcho-

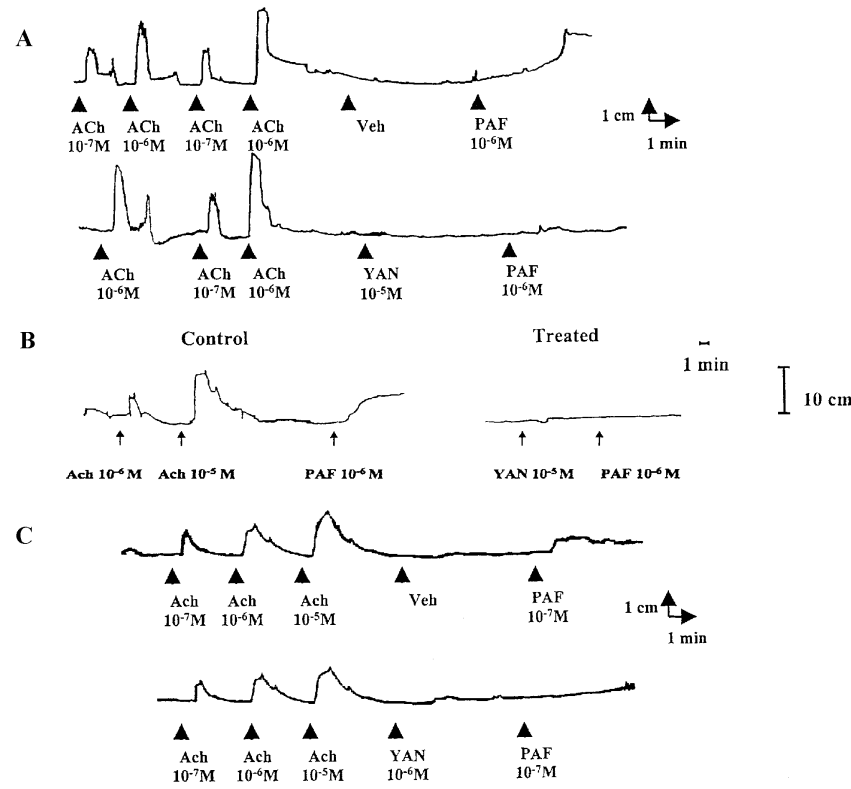

Fig. 2 The effect of yangambin (YAN) $\left(10^{-6} \mathrm{M} ; 10^{-5} \mathrm{M}\right)$ on PAF $\left(10^{-6} \mathrm{M} ; 10^{-7} \mathrm{M}\right)$ induced rat jejunum $(\mathbf{A})$, ileum $(\mathbf{B})$ and colon $(\mathbf{C})$ contractions. The intestine sections were allowed to equilibrate for at least $30 \mathrm{~min}$ before their viability was evaluated by measuring the contractile response to different concentrations of acetylcholine (ACh); YAN was incubated in the organ bath for 5 min before the stimulation with PAF. In control sections PAF was added 5 min after the incubation of the tissue with YAN vehicle (Veh). This is one representative experiment out of 3 repetitions. line $\left(10^{-7} \mathrm{M}\right)$ and histamine $\left(10^{-7} \mathrm{M}\right)$ (Fig. 3) indicating that YAN is a selective antagonist for PAF in this model. The duodenum segments did not respond to PAF $\left(10^{-7}\right.$ to $\left.10^{-6} \mathrm{M}\right)$ and therefore could not be tested for the effect of YAN (data not shown). The well-established PAF antagonist, WEB 2086, inhibited the contractions induced by PAF in all the tissues tested (data not shown).

\section{Effect of PAF, YAN and WEB 2086 on isolated rat stomach fundus}

PAF $\left(10^{-7} \mathrm{M}\right.$ to $\left.10^{-6} \mathrm{M}\right)$ induced contraction of the isolated stomach strips which was not inhibited by prior administration of YAN in a concentration up to $10^{-5} \mathrm{M}$ (Fig. $\left.4 \mathbf{a}, \mathbf{b}, \mathbf{c}, \mathbf{d}\right)$. In contrast, WEB $2086\left(10^{-6} \mathrm{M}\right.$ to $\left.5 \times 10^{-6} \mathrm{M}\right)$ was effective to inhibit PAF-induced contractions of the isolated rat stomach fundus (Fig. $5 \mathbf{a}, \mathbf{b})$. Highest concentrations of YAN $\left(3 \times 10^{-5} \mathrm{M}\right)$ elicited a contraction of the stomach fundus strips. Pretreatment with WEB $2086\left(5 \times 10^{-6} \mathrm{M}\right)$, a concentration that was able to completely inhibit PAF-induced contraction, did not inhibit the contraction elicited by YAN (Fig. 6), indicating that YAN is not acting through the PAF receptor to trigger contraction.

\section{Effect of PAF and YAN on rat tracheal and bronchial rings}

In agreement with previous studies (14), tracheal and bronchial rings were also insensitive to PAF stimulation in concentrations up to $10^{-6} \mathrm{M}$ and therefore could not be tested for the effect of YAN (data not shown).

\section{Effect of YAN and WEB 2086 on PAF-induced vascular}

permeability increase in duodenum, jejunum, ileum, colon, and mesentery of rat

The intravenous injection of PAF elicited a significant increase of EB extravasation in the duodenum, jejunum, ileum, colon and mesentery. Both PAF antagonists, YAN $(30 \mathrm{mg} / \mathrm{kg})$ and WEB $2086(1 \mathrm{mg} / \mathrm{kg})$, significantly reduced the EB extravasation in all tissues (Table 1). In contrast, YAN alone did not show any effect on basal EB extravasation levels.

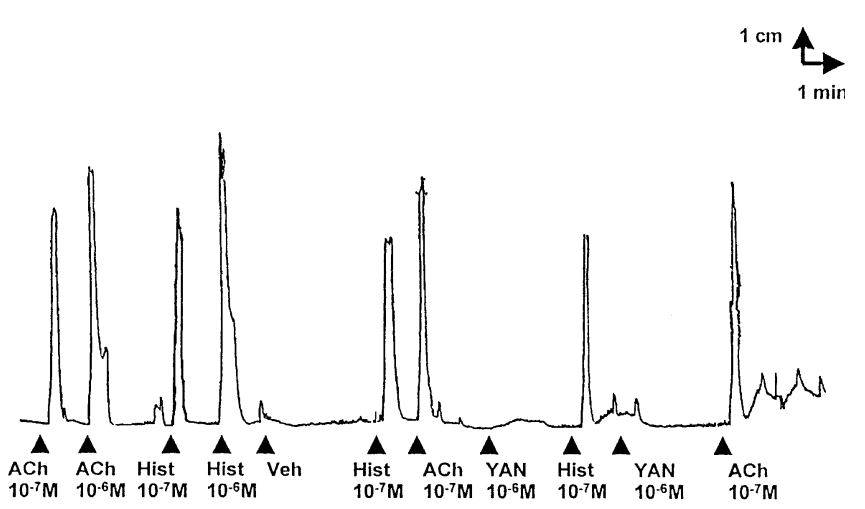

Fig. 3 The effect of yangambin on acetylcholine and histamine induced rat ileum contractions. Ileum sections were equilibrated in the organ bath for 30 min before the stimulation (arrows) with acetylcholine (ACh) $\left(10^{-6} \mathrm{M} ; 10^{-7} \mathrm{M}\right)$ or histamine (Hist) $\left(10^{-6} \mathrm{M} ; 10^{-7} \mathrm{M}\right)$. Yangambin (YAN) or its vehicle (Veh) were incubated for $5 \mathrm{~min}$ in the organ bath before the stimulation with acetylcholine and histamine. This is one representative experiment out of 3 repetitions. 


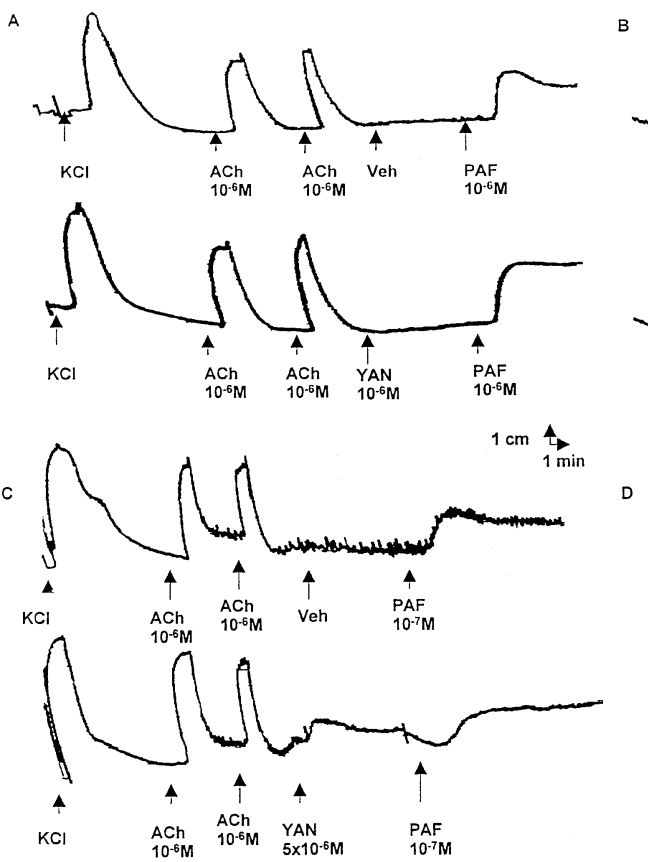

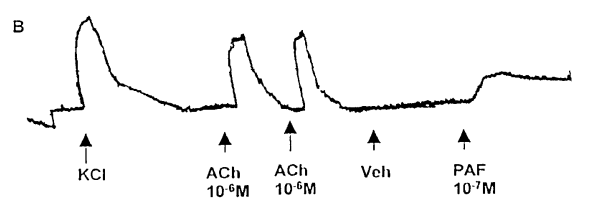
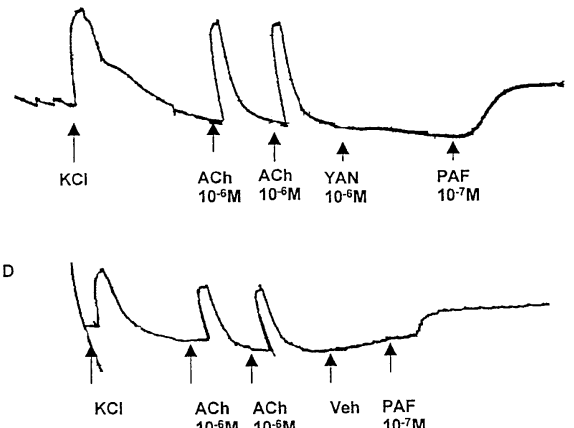

$\mathrm{KCl} \quad \begin{array}{llll}\mathrm{ACh} & \mathrm{ACh} \\ 10^{-6} \mathrm{M} & 10^{-6} \mathrm{M}\end{array}$ Veh $\begin{aligned} & \mathrm{PAF} \\ & 10^{-7} \mathrm{M}\end{aligned}$

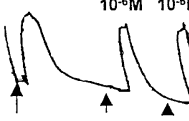

$\mathrm{KCl} \quad \mathrm{ACh} A C h$ YAN PAF
Fig. 4 The effect of yangambin (YAN) on PAF-induced contractions of rat stomach fundus. Stomach strips were allowed to equilibrate in the organ bath for $1 \mathrm{~h}$ before their viability were assayed by measuring the contractile response to $\mathrm{KCl}$ and acetylcholine (ACh) $\left(10^{-6} \mathrm{M}\right)$. Yangambin $10^{-6} \mathrm{M}(\mathbf{A}, \mathbf{B}) ; 5 \times$ $10^{-6} \mathrm{M}(\mathrm{C})$ or $10^{-5} \mathrm{M}$ (D) was incubated in the organ bath for 5 min before the stimulation with PAF $\left(10^{-6} \mathrm{M}, 10^{-7} \mathrm{M}\right)$. In control stomach strips PAF was added 5 min after the incubation of the tissue with YAN vehicle (Veh). This is one representative experiment out of 5 repetitions.

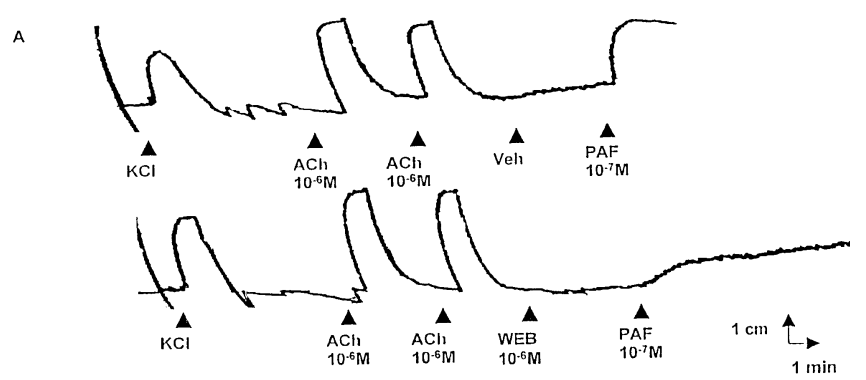

B
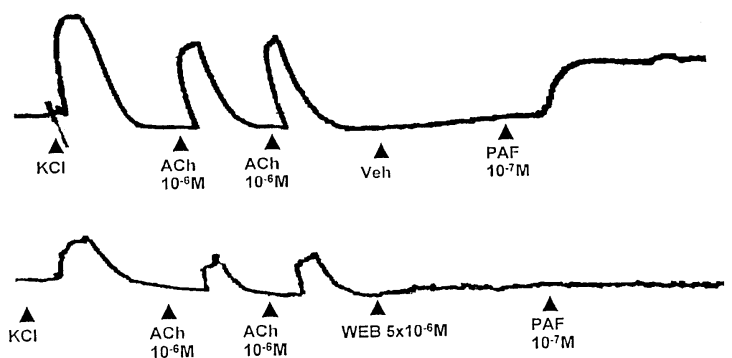

Fig. 5 The effect of WEB $208610^{-6} \mathrm{M}(\mathbf{A})$ or $5 \times 10^{-6} \mathrm{M}(\mathbf{B})$ on PAF $\left(10^{-7} \mathrm{M}\right)$ induced contractions of the rat stomach fundus. Stomach strips were allowed to equilibrate in the organ bath for $1 \mathrm{~h}$ before their viability were assayed by measuring the contractile response to $\mathrm{KCl}$ and acetylcholine (ACh) $\left(10^{-6} \mathrm{M}\right)$. WEB 2086 was incubated in the organ bath for 5 min before the stimulation with PAF. In control stomach strips PAF was added 5 min after the incubation of the tissue with WEB 2086 vehicle (Veh). This is one representative experiment out of 3 repetitions.

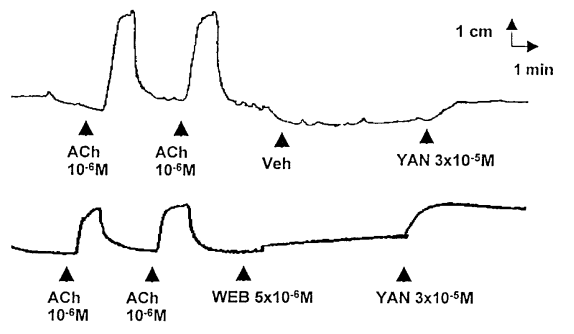

Fig. 6 The effect of WEB $2086(5 \times$ $\left.10^{-6} \mathrm{M}\right)$ on YAN $(3 \times$ $10^{-5} \mathrm{M}$ ) induced rat stomach fundus contractions. Stomach strips were allowed to equilibrate in the organ bath for $1 \mathrm{~h}$ before their viability were assayed by measuring the contractile response to $\mathrm{KCl}$ and acetylcholine (ACh) $\left(10^{-6} \mathrm{M}\right)$. WEB 2086 was incubated in the organ bath for 5 min before the stimulation with YAN. In control stomach strips YAN was added $5 \mathrm{~min}$ after the incubation of the tissue with WEB 2086 vehicle (Veh). This is one representative experiment out of 3 repetitions.

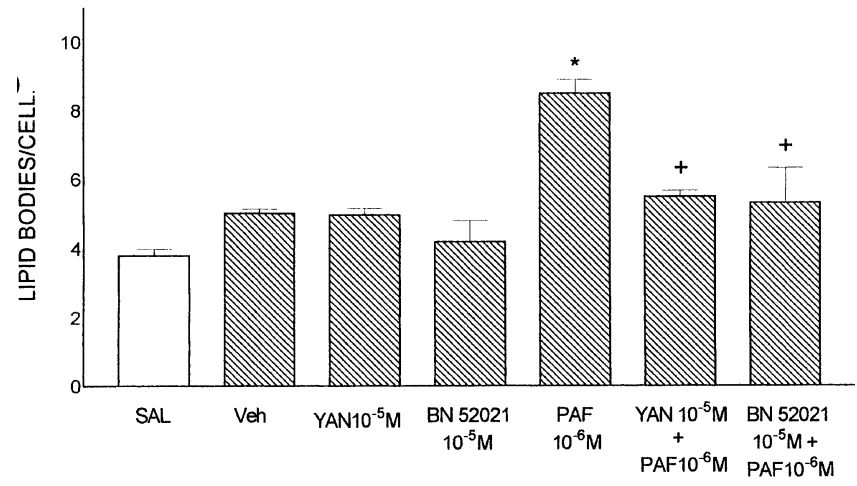

Fig. 7 The effect of yangambin $\left(10^{-5} \mathrm{M}\right)$ and $B N 52021\left(10^{-5} \mathrm{M}\right)$ on PAF $\left(10^{-6} \mathrm{M}\right)$ induced-lipid body formation in macrophages obtained from the peritoneal cavity of $\mathrm{C} 3 \mathrm{H} / \mathrm{He}$ mice. Macrophages were incubated with YAN, BN 52021 or vehicle (Veh) 15 min prior to the addition of PAF. Lipid body formation was analyzed $1 \mathrm{~h}$ after the addition of PAF. Bars represent the mean \pm S.E.M. from 3 independents assays. Statistically significant $(P<0.001)$ differences are indicated by an asterisk. 
Table 1 Effect of YAN and WEB 2086 on PAF-induced vascular permeability increase in duodenum, jejunum, ileum, colon, and mesentery of rat.

\begin{tabular}{llllll}
\hline $\begin{array}{l}\text { Tissue } \\
\text { Group }\end{array}$ & $\begin{array}{l}\text { Duodenum } \\
(\%)\end{array}$ & $\begin{array}{l}\text { Jejunum } \\
(\%)\end{array}$ & $\begin{array}{l}\text { lleum } \\
(\%)\end{array}$ & $\begin{array}{l}\text { Colon } \\
(\%)\end{array}$ & $\begin{array}{l}\text { Mes. } \\
(\%)\end{array}$ \\
\hline WEB/ & 100 & 100 & 100 & 100 & 100 \\
PAF & $(n=5)+$ & $(n=5)+(n=5)+(n=5)+$ & $(n=5)+$ \\
YAN $/$ & 100 & 100 & 100 & 100 & 100 \\
PAF & $(n=5)+$ & $(n=5)+(n=5)+(n=5)+$ & $(n=4)+$ \\
\hline
\end{tabular}

Results are expressed as percent of inhibition of PAF induced increase in vascular permeability. Vascular permeability was assayed as the amount $(\mu \mathrm{g})$ of AE per gram of dry weight of the tissue. The number of experiments is shown in parentheses. $(+) \mathrm{p}<0.001$ vs PAF.

\section{Effect of YAN and BN 52021 on PAF-induced lipid body formation in mice macrophages}

Incubation of peritoneal macrophages with PAF caused a significant increase in the number of lipid bodies in these cells. Prior treatment of the cells with YAN $\left(10^{-5} \mathrm{M}\right)$ or BN 52021 $\left(10^{-5} \mathrm{M}\right)$ completely prevented PAF-induced lipid body formation (Fig. 7).

\section{Discussion}

PAF acts via interaction with specific receptors on the membrane surface of responsive cells (4). Through hydropathy profile analysis of cloned PAF receptors it was demonstrated that this protein has seven hydrophobic transmembrane segments characteristic of the $G$ protein coupled family of receptors and that the cytoplasmic tail contains four serines and five threonines that may function as possible phosphate acceptors (4). Phosphorylation of these residues could represent a rapid way of controlling receptor activity leading to receptor desensitization (4). In the experiments described here, PAF evoked a significant contraction of isolated rat jejunum, ileum, colon and stomach fundus. The contractions were characterized by rapid desensitization to further stimulus with PAF. These results are in agreement with the studies described previously (15), (16). Because of this characteristic it was not possible to construct a cumulative concentration-response curve with PAF using the same muscle segment. It is important to note that desensitization was restricted to PAF and it was not observed with $\mathrm{ACh}$, His or $\mathrm{KCl}$.

Our results indicated that the different tissues showed different sensitivity to PAF stimulation. For instance, duodenum, tracheal and bronchial rings did not respond to PAF stimulation at all doses of PAF utilized whereas colon segments were less sensitive than jejunum and ileum. These differences in sensitivity are probably related to differences in the density of receptors expressed on those tissues.

There is some pharmacological evidence suggesting the existence of PAF receptor subtypes in macrophages, PMN leukocytes and platelets (11), (17). Most of this evidence is based on the observation that some competitive PAF-receptor antagonists have differential potencies on platelets and PMN leukocytes (17), (18).
We have previously demonstrated, through binding assays, that YAN is a competitive antagonist of PAF receptors in platelets (8). In vitro functional assays agreed with that since YAN was able to inhibit PAF-induced platelet aggregation causing a parallel shift to the right of the PAF concentration-response curve. Moreover, YAN could also selectively block the cardiovascular collapse and thrombocytopenia induced by PAF in rabbits (9). Interestingly, YAN failed against the neutropenia observed concomitantly with thrombocytopenia and cardiovascular collapse in this model (9). In vitro assays showed that YAN could neither inhibit PAF-induced neutrophil chemotaxis (8) nor the binding of PAF to human neutrophils (10). Taken together, these results suggest that YAN is able to discriminate putative PAF receptors subtypes expressed on platelets and PMN. Interestingly, the results of the present study showed that YAN in concentrations above those necessary to block the PAF responses in the ileum and jejunum, did not inhibit the contractions induced by PAF in rat stomach fundus, suggesting that the PAF receptors expressed on the stomach fundus share similarities, concerning their sensitivity to YAN, with those expressed on neutrophils but not with those expressed on platelets, ileum and jejunum. Another possibility to explain the discrepancy between the lack of effect of YAN in the stomach in contrast to its inhibitory effect on the jejunum and ileum would be that the effect of PAF on the stomach strips is receptor-independent. Since WEB 2086, a reference antagonist of PAF (18), inhibited the contractile effect of PAF in the stomach this possibility seems rather unlikely.

While trying to inhibit PAF-induced stomach strips contraction with high concentrations of YAN we noted that YAN itself elicited a significant contraction of stomach strips in concentrations above $3 \times 10^{-5} \mathrm{M}$. This led us to investigate if YAN could be acting as a partial agonist to the PAF receptor. Nevertheless, this was not the case since the contractions induced by YAN were not antagonized by WEB 2086 in concentrations that completely blocked PAF-induced contraction of stomach fundus. Moreover, YAN was able to contract stomach strips that had been previously desensitized by prior exposure to PAF (data not shown). The mechanism responsible for the contractile effect induced by high doses of YAN is still unknown and additional experiments are needed to further clarify this issue.

The venules in the intestinal tract expressed receptors that were similar to those expressed by the jejunum, ileum and colon segments in respect to their sensitivity to YAN. Our results showed that 10 min after an intravenous injection of PAF into rats, a marked extravasation of plasma proteins was observed in the intestine and mesentery. This effect was expected since PAF was shown to increase the endothelial permeability in capillaries and post capillary venules (19). Both YAN and WEB 2086 significantly inhibited this effect.

PAF-induced activation of peritoneal macrophages was also YAN sensitive. This was clearly demonstrated by studying the lipid body formation in cells that were stimulated by PAF. PAF-induced lipid body formation has been studied in neutrophils (2) and eosinophils (20). These structures increase in number in activated cells and seem to be related to the production of arachidonate metabolites during inflammatory reactions (2). In our study we showed that YAN as well as BN 
52021 potently inhibited lipid body formation in peritoneal macrophages stimulated by PAF.

Our data, supported by the previous reports (8), (9), indicate that there may be at least two different subtypes of PAF receptors, clearly distinguished by the lignan yangambin. The receptors expressed on macrophages, venules, platelets and the smooth muscle of the jejunum, ileum and colon are sensitive to both YAN and classical PAF antagonists such as WEB 2086 and BN 52021, while the receptors expressed on neutrophils and stomach fundus are sensitive only to the classical PAF antagonists but not to YAN. Although molecular biology experiments failed to identify PAF receptors subtypes, there seems to be clear pharmacological differences in the sensitivity to PAF antagonists in some tissues. The physiological/ pathological importance of this fact, as well as potential of YAN as a therapeutic agent or a research tool is not a settled issue and deserves further investigation.

\section{References}

${ }^{1}$ Braquet P, Touqui L, Shen TY, Vargaftig BB. Pharmacol. Rev. 1987; 39: $97-133$

${ }^{2}$ Bozza PT, Payne JL, Goulet JL, Weller PF. J. Exp. Med. 1996; 183: $1515-25$

${ }^{3}$ Stewart AG, Phillips WA. Br. J. Pharmacol. 1989; 98: $141-8$

${ }^{4}$ Honda Z, Nakamura M, Miki I, Minami M, Watanabe T, Seyama Y, Okado H, Toh H, Ito K, Miyamoto T, Shimizu T. Nature 1991; 349: $342-6$

${ }^{5}$ Nakamura M, Honda Z, Izumi T, Sakanka C, Mutoh H, Minami M, Bito H, Seyama Y, Matsumoto T, Noma M, Shimizu T. J. Biol. Chem. 1991; 266: 20400-5

${ }^{6}$ Shen TY, Hwang SB, Chang MN, Doebber TW, Lam MHT, Wu MS, Wang X, Han GQ, Li RZ. Biochemistry 1985; 82: $672-6$

${ }^{7}$ Biftu T, Stevenson R. Phytother. Res. 1987 1: 97-106

${ }^{8}$ Castro-Faria-Neto HC, Bozza PT, Cruz HN, Silva CLM, Violante FA, Barbosa-Filho JM, Thomas GM, Martins MA, Tibiriça EV, Noel F, Cordeiro RSB. Planta Med. 1995; 61: $101-5$

${ }^{9}$ Castro-Faria-Neto HC, Araújo CV, Moreira S, Bozza PT, Thomas GM, Barbosa-Filho JM, Cordeiro RSB, Tibiriça EV. Planta Med. 1995; 61: $106-12$

${ }^{10}$ Herbert JM, Castro-Faria-Neto HC, Barbosa-Filho JM, Cordeiro RSB, Tibiriça E. J. Lipid Mediators Cell Signalling 1997; 17: 1 - 14

${ }^{11}$ Lambrecht G, Parnham MJ. Br. J. Pharmac. 1986; 87: 287-9

12 Jancar S, Sirois MG, Carrier J, Braquet P, Sirois P. Inflammation 1991; 15 (5): 347-54

${ }^{13}$ De Queiroz Paulo M, Kaplan MAC, Laprévote O, Roblot F, Hocquemiller R, Cavé A. Fitoterapia 1991; LXII: 150-2

${ }^{14}$ Corfield DR, Webber SE, Widdicombe JG. Br. J. Pharmacol. 1991; 103: $1740-44$

15 Tokumura A, Furkuzawa K, Tsukatani H. J. Pharm. Pharmacol. 1984; 36: $210-2$

${ }^{16}$ Levy JV. Biochem. Bioph. Res. Commun. 1987; 146: 855-60

${ }^{17}$ Hwang SB. J. Biol. Chem. 1988; 263: 3225-33

18 O'Donnell SR, Barnett CJK. Br. J. Pharmacol. 1988; 94: 437-42

${ }^{19}$ Thureson-Klein A, Hedqvist A, Öhlen A, Raud J, Lindbom L. Pathol. Immunopathol. Res. 1987; 6: 190-206

${ }^{20}$ Bozza PT, Yu W, Penrose JF, Morgan ES, Dvorak AM, Weller PF. J. Exp. Med. 1997; 186: 909-20

\section{Dr. Hugo Castro-Faria-Neto}

Laboratório de Imunofarmacologia

Departamento de Fisiologia e Farmacodinâmica, IOC

Fundação Oswaldo Cruz

Av. Brasil, 4365, Manguinhos, CEP 21045-900

Rio de Janeiro, RJ

Brazil

E-mail: hcastro@gene.dbbm.fiocruz.br

Fax: +55-21 590-9490 